\title{
Antioxidants and Lipid Peroxidation Status In Women with Breast Cancer
}

\author{
Seraj AKa, Shankhar Ma ${ }^{\mathrm{a}}$, Raju KD ${ }^{\mathrm{d}}$, Punam Ja, Anju Pb, Rajat KA \\ aDepartment of Biochemistry, \\ ${ }^{b}$ Department of Pathology \\ 'Department of Surgery, B.P. Koirala Institute of Health Sciences, Dharan, Nepal \\ ${ }^{d}$ Department of Biochemistry, UCMS, Bhairahawa, Nepal
}

\begin{abstract}
Introduction: Breast cancer is one of the most common malignancy in women and is the leading cause of cancer related death worldwide. Reactive oxygen species (ROS) play an important role in the development of tumours. Several mechanisms leading to oxidative stress have been proposed in cancer patients. In this study we aimed to measure and compare the levels of zinc, superoxide dismutase, catalase, vitamin C, vitamin E, and malondialdehyde in breast cancer patients and age matched healthy controls. Methods: In this comparative cross sectional study, 30 confirmed breast cancer cases and 30 age and sex matched controls were enrolled after taking their consent. Blood sample was collected in EDTA vial, and the parameters of oxidative stress were evaluated by spectrophotometric and atomic absorption spectrophotometric methods. Results: Zinc and MDA level were significantly higher $(\mathrm{p}<0.001)$ in cases $(106.4 \mu \mathrm{g} / \mathrm{dl}$ and $7.12 \mathrm{nmol} / \mathrm{ml})$ compared to controls $(89.8 \mu \mathrm{g} /$ $\mathrm{dl}$ and $3.99 \mathrm{nmol} / \mathrm{ml})$. In contrast, there were lower catalase, vitamin $C$ and $\mathrm{E}$ levels in cases $(28.7 \pm 14.56$, $0.92 \pm 0.35$ and $0.68 \pm 0.13 \mathrm{mg} / \mathrm{dl})$ compared to controls $(37.1 \pm 14.7,1.62 \pm 0.59$ and $1.02 \pm 0.22 \mathrm{mg} / \mathrm{dl})$ and were statistically significant $(p<0.05$ and $p<0.001)$. Whereas, superoxide dismutase was lower in cases compared to controls, but was not statistically significant. Conclusion: Zinc was found to be higher in our study as it is a pivotal element in all rapidly growing tissues. Enhanced lipid peroxidation observed in the circulation of breast cancer patients in our study can be attributed to over production of ROS and deficiency of antioxidant defences. Oxidative stress in cancer cells may trigger excessive consumption of antioxidants as a compensatory mechanism which lead to its lower concentration.
\end{abstract}

KEYWORDS: Breast cancer, zinc, superoxide dismutase, catalase, malondialdehyde

\section{INTRODUCTION}

The aerobic metabolism, occurring in the cell leads to generation of small amount of reactive oxygen species (ROS) in organisms. ${ }^{1}$ ROS acts like a double edge sword. Small amount of ROS are indispensable for proper biochemical processes, however excessive production or inefficient removal leads to oxidative stress that may can cause oxidative damage to biomolecules resulting in lipid peroxidation, mutagenesis, and carcinogenesis. ${ }^{2}$ Body has develop an efficient method to tackle with these free radicals

Corresponding author:

Dr. Seraj Ahmed Khan MD

Assistant Professor

Department of Biochemistry

B.P. Koirala Institute of Health Sciences

Dharan-18, Nepal, Pin Code: 56700

Phone: 00977-9842039061

Email:drserajkhan@gmail.com by various cellular defence mechanisms, consisting of enzymatic (catalase, glutathione peroxidase, superoxide dismutase) and non-enzymatic (vit. E, vit.C, glutathione, carotenoids and flavonoids) components. ${ }^{3}$

Breast cancer is one of the most common cancer in women and is the leading cause of cancer related death worldwide. ${ }^{4}$ The exact aetiology of breast cancer is still unknown, but numerous studies have shown the role of ROS in the pathogenesis of cancer. ${ }^{5-10}$ Oxidative damage results from the interaction of ROS with cellular macromolecules such as protein, lipid and DNA. ${ }^{11,12}$

ROS reacts with polyunsaturated fatty acids to induce the release of toxic and reactive aldehyde metabolites such as malondialdehyde (MDA), one of the end products of lipid peroxidation. MDA may be involved in tumor promotion by reacting with various cellular processes. ${ }^{13}$ Superoxide dismutase (SOD, EC 1.15.1.1) and catalase (CAT, EC 1.11.1.6) that catalyze the detoxification of superoxide anion $\left(\mathrm{O}_{2}\right)$ and hydrogen peroxide $\left(\mathrm{H}_{2} \mathrm{O}_{2}\right)$, respectively, protect the cell against ROS-induced damage. ${ }^{14}$ Zinc is an important element for so many enzymes in the body, also it acts as direct 
scavenger of free radicals and protects from oxidative damage. But in case of imbalance between oxidant and antioxidant, the defence mechanism loses the battle. So many enzymes are rendered function less and can leads to the sequestration of microelements in the blood.

The present study was therefore designed to examine the lipid peroxidation status by estimating MDA and the antioxidant status through SOD, catalase, vitamin $\mathrm{C}$ and vitamin $\mathrm{E}$ and Zinc level in women with breast cancer.

\section{MATERIALS AND METHODS}

Thirty newly diagnosed breast cancer patients, from B.P. Koirala Institute of Health Sciences, Dharan, Nepal, who had neither undergone any previous treatment for their tumours nor were using hormones, oral contraceptives etc were recruited in the study. All were non-smokers and none of them had concomitant diseases such as diabetes mellitus, liver disease, or rheumatoid arthritis. This comparative cross sectional study was carried out from July 2010 to August 2011. Mean age of the patients was $48.1 \pm 9.35$ yrs. There were 30 female healthy controls and their mean age was $45.2 \pm 10.9 \mathrm{yrs}$. Informed and written consent was obtained from all participants. Of the 30 patients, 29 were of infiltrative ductal carcinoma and 1 infiltrative lobular carcinoma.

Blood samples were collected with EDTA as anticoagulant $(1 / 10, \mathrm{v} / \mathrm{v})$ beforeany treatment modality such as chemotherapy and surgery was instituted to the patients. Then, erythrocytes were washed with $0.9 \%$ $\mathrm{NaCl}$ solution three times, and washed erythrocytes were haemolysed by the addition of Tris- $\mathrm{HCl}$ buffer, $\mathrm{pH} 7.2,0.015 \mathrm{M}$. Haemoglobin $(\mathrm{Hb})$ concentrations of the samples were measured by cyanmethaemoglobin method. ${ }^{15}$ The haemolysate and plasma of the subjects were kept at $-20^{\circ} \mathrm{C}$ till biochemical analysis.
Lipid peroxidation status was determined by method of Yagi. ${ }^{16}$ The pink colour produced by the reaction of thiobarbituric acid with malondialdehyde, was estimated at $532 \mathrm{~nm}$. Assay of SOD was based on the $50 \%$ inhibition of the formation ofnicotinamide adenine dinucleotide (NADH)-phenazine methosul fate-nitroblue tetrazolium formazan at 520 nm. ${ }^{17}$ Catalase was estimated by dichromate in acetic acid is reduced to chromic acetate when heated in the presence of $\mathrm{H}_{2} \mathrm{O}_{2}$, with the formation of perchromic acid as an unstable intermediate and read spectrophotometrically at $570 \mathrm{~nm} .{ }^{18}$ Determination of ascorbic acid depends on the reduction of ferric ion to ferrous ion by ascorbic acid as red-orange, a, a'dipyridal complex. ${ }^{19}$ Vitamin $\mathrm{E}$ determination is based on Emmerie Engel procedure. ${ }^{20}$ Zinc was estimated by Flame Atomic Absorption Spectrophotometry. ${ }^{21}$

Statistical analyses were performed using the statistical package for social sciences version 11.5 (SPSS Inc. USA). Data were expressed as mean \pm SD and frequency. Student t-test and Mann-Whitney $U$ test was performed to compare means of the biochemical parameters between cases and controls. Probability of significance was set at $5 \%$ level of significance.

\section{RESULTS}

The descriptive characteristics of cases and control is presented in Table I. Table II shows the lipid peroxidation status and zinc level in breast cancer patients and healthy controls. Both lipid peroxidation by measuring MDA and zinc level were higher in patients compared to control ( $p<0.001$ and $<0.05$, respectively). The different antioxidant status in the study subjects is presented in Table III. There is slight decrease in SOD activity in patients but statistically insignificant, whereas catalase activity is decreased significantly in patients compared to control $(\mathrm{p}<0.05)$ as depicted in Table III. The level of vitamin $E$ and $C$ were significantly lower in patients when compared to control $(p<0.001)$. 
Table I. Descriptive characteristics of cases and controls.

\begin{tabular}{|c|c|c|c|}
\hline Characteristics & Cases $(\mathrm{N}=30)$ & Controls $(\mathrm{N}=30)$ & $P$ \\
\hline Age (Year) & $48.1 \pm 9.35$ & $45.2 \pm 10.9$ & \\
\hline BMI (Kg/m2) & $24.3 \pm 2.70^{*}$ & $26.7 \pm 3.37$ & \\
\hline Age of Menarche (Year) & $12-15$ & $12-14$ & \\
\hline \multicolumn{4}{|l|}{ Married } \\
\hline Yes $(n)$ & 26 & 29 & \\
\hline No (n) & 4 & 1 & \\
\hline \multicolumn{4}{|l|}{ Dietary habit } \\
\hline Vegetarian & 2 & 9 & \\
\hline Non vegetarian & 28 & 21 & \\
\hline \multicolumn{4}{|l|}{ Pregnancy history } \\
\hline Yes $(n)$ & 24 & 27 & \\
\hline No $(n)$ & 6 & 3 & \\
\hline \multicolumn{4}{|l|}{ Menopausal status } \\
\hline Premenopausal (n) & 15 & 13 & \\
\hline Postmenopausal (n) & 15 & 17 & \\
\hline \multicolumn{4}{|l|}{ Cancer site } \\
\hline Left (n) & 12 & NA & \\
\hline Right (n) & 18 & NA & \\
\hline \multicolumn{4}{|l|}{ Clinical status } \\
\hline $\begin{array}{l}\text { Infiltrative ductal carcinoma } \\
\text { (n) }\end{array}$ & 29 & NA & \\
\hline $\begin{array}{l}\text { Infiltrative lobular carcinoma } \\
\text { (n) }\end{array}$ & 1 & NA & \\
\hline
\end{tabular}

${ }^{*} \mathrm{p}<0.05$ compare to control. NA= Not Applicable. $B M I=$ Basal Metabolic Index

Table II. Lipid peroxidation status and zinc level in case and controls.

\begin{tabular}{lccl}
\hline Parameters & Breast cancer patients & Controls & $\mathrm{p}$ \\
\hline MDA $(\mathrm{nmol} / \mathrm{ml})$ & $7.12 \pm 1.95^{* *}$ & $3.99 \pm 1.30$ & $<0.001$ \\
Zinc $(\mu \mathrm{gm} / \mathrm{dl})$ & $106.4 \pm 33.3^{*}$ & $89.8 \pm 27.9$ & $<0.05$ \\
\hline
\end{tabular}

${ }^{*} \mathrm{p}<0.05$ compare to control ${ }^{* *} \mathrm{p}<0.001$ compare to control MDA = Malondialdehyde 
Table III. Antioxidant status in case and controls.

\begin{tabular}{llll}
\hline Parameters & Case & Controls & P \\
\hline SOD $(\mathrm{U} / \mathrm{gmHb})$ & $1004.8 \pm 74.8$ & $1049.2 \pm 95.5$ & \\
Catalase $(\mathrm{U} / \mathrm{gmHb})$ & $28.7 \pm 14.6^{*}$ & $37.1 \pm 14.7$ & $<0.05$ \\
Vitamin C $(\mathrm{mg} / \mathrm{dl})$ & $0.92 \pm 0.35^{* *}$ & $1.62 \pm 0.59$ & $<0.001$ \\
Vitamin E $(\mathrm{mg} / \mathrm{dl})$ & $0.68 \pm 0.13^{* *}$ & $1.02 \pm 0.22$ & $<0.001$ \\
\hline
\end{tabular}

* $p<0.05$ compare to control ${ }^{* *} p<0.001$ compare to control

$\mathrm{SOD}=$ Superoxide dismutase

\section{DISCUSSION}

Breast cancer is one of the most common malignancy in women, not only in the Western world, but also throughout the worldwide. ${ }^{22}$ Several studies conducted in recent past has showed that increase oxidative stress and lipid peroxidation is implicated in its carcinogenesis. ${ }^{23-26} \mathrm{MDA}$ is a marker of lipid peroxidation resulting from oxidation of polyunsaturated fatty acids in membranes induced by free radicals. Studies have shown positive association between lipid peroxidation and cancer. ${ }^{10,13,27-29}$ Lipid peroxidation was measured as MDA in various studies and was found to be higher in many studies. ${ }^{25,} 29$ Similar finding was observed in our study. The exact mechanism how these lipid peroxides induces the carcinogenesis process or it is the result of cancer, is still not clear. There have been accumulating evidence that shows the reduced level of SOD and catalase in breast cancer patients. ${ }^{30-33}$ Yuvaraj $^{34}$ showed that the various circulating enzymatic and nonenzymatic antioxidants were low in a group of women with breast cancer. The results of the above studies are in accordance with the results obtained in our study which shows a low level of antioxidant status in the women with breast cancer. But the decrease in SOD is not significant in the breast cancer patients, which contradicts the findings of the above studies. Several studies which showed a rise in the level of antioxidant enzymes7,35 suggested that the ROS generated might induce the antioxidant enzymes in order to eliminate the excessive free radicals that were produced. These findings contradicted our results.

In this study, enzymatic and non-enzymatic antioxidants, SOD, catalase, vitamin C, vitamin E and zinc were measured. The result obtained supports the fact that the oxidative stress in cancer patients exhausts the antioxidant mechanism of our body that leads to its depletion. Vitamin C, the major circulating water-soluble antioxidant which acts as a free radical scavenger, can react with a vitamin $\mathrm{E}$ radical to yield a vitamin $C$ radical while regenerating vitamin E. Several studies have shown the decrease in the vitamin $C$ and $E$ level in breast cancer patients, which were in agreement with the finding of the present study. ${ }^{9}, 10,36$ Few studies showed that risks of breast cancer recurrence and disease-related mortality were reduced among women using vitamin $\mathrm{C}$ and vitamin $\mathrm{E}$ supplements for more than three years. ${ }^{36}$

Zinc is a pivotal element in all rapidly growing tissues because it is an important component of DNA and RNA polymerase, and play an important role by acting as a modulatory and protective action for the growth of both normal and cancer cells. ${ }^{37-38}$ The study done by Cavallo ${ }^{39}$ showed that the plasma zinc level was significantly higher in patients as compared to control group and this finding is in agreement with our result. The higher zinc level and its role as cancer promoter might be attributed by the capability of tumour tissues to incorporate $\mathrm{Zn}$ and withhold it, as few studies have pointed out. But contradictory results have also been reported in the study of trace elements in breast cancer patients. ${ }^{40-42}$

\section{CONCLUSION}

In conclusion, breast cancer is related to increased lipid peroxidation in plasma with concomitant decrease of body's antioxidant capacity. In overall, findings of the present study support the importance of body's antioxidant mechanism in the aetiology of breast cancer. It may be also suggested that increased oxidative stress in breast cancer patients may also be attributed to the altered trace elements level in such patients. Thus, further larger scale studies are required to elucidate the actual relation of these components with the disease.

\section{ACKNOWLEDGEMENTS}

This study was funded by the Nepal India Corpus Fund, B.P. Koirala Institute of Health Sciences and the authors fully acknowledge it. We also thanks to the SEAM-N team Biratnagar, Nepal for their guidance and support by allowing us to use their infrastructure to perform Atomic Absorption Spectrophotometry. 


\section{REFERENCES}

1. Matés JM, Sánchez-Jiménez FM. Role of reactive oxygen species in apoptosis: implications for cancer therapy. The Int J Biochem Cell Biol 2000; 32:157-70.

2. MatÉs JM, Pérez-Gómez C, De Castro N. Antioxidant enzymes and human diseases. Clin Biochem 1999;32:595-603.

3. Hou M-F, Lin S-B, Yuan S-SF, et al. The clinical significance between activation of nuclear factor kappa B transcription factor and overexpression of HER-2/neu oncoprotein in Taiwanese patients with breast cancer. Clin Chimi Acta 2003; 334: 137-44.

4. Ahmedin Jemal D, Tiwari RC, Murray T, et al. Cancer statistics. CA Cancer J Clin 2004: 8-29.

5. Thangaraju M, Vijayalakshimi T \& Sachdanandam P. Effect of tamoxifen on lipid peroxide and antioxidative system in postmenopausal women with breast cancer. Cancer 1994; 74:78-82.

6. Punnonen K, Ahotupa M, Asaishi K, Hyoty M, Kudo R, Punnonen R. Antioxidant enzyme activities and oxidative stress in human breast cancer. J Cancer Res Clin Oncol 1994; 120:374-7.

7. Portakal O, Ozkaya O, Erden Inal M, et al. Coenzyme Q10 concentrations and antioxidant status in tissues of breast cancer patients. Clin Biochem 2000; 33:279-84.

8. Iscan M, Coban T, Cok I, et al. The organochlorine pesticide residues and antioxidant enzyme activities in human breast tumors: is there any association? Breast Cancer Res Treat 2002; 72: 173-82.

9. Kumaraguruparan R, Subapriya R, Viswanathan P, Nagini S. Tissue lipid peroxidation and antioxidant status in patients with adenocarcinoma of the breast. Clinica Chim Acta 2002; 325:165-70.

10. Kumaraguruparan R, Subapriya R, Kabalimoorthy $J$, Nagini S. Antioxidant profile in the circulation of patients with fibroadenoma and adenocarcinoma of the breast. Clin Biochem 2002; 35:275-9.

11. Klaunig JE, Xu Y, Isenberg JS, et al. The role of oxidative stress in chemical carcinogenesis. Environ Health Perspect 1998; 106:289-95.

12. Bandyopadhyay U, Das D, Banerjee RK. Reactive oxygen species: oxidative damage and pathogenesis. Current Science 1999; 77:658-66.

13. Vaca CE, Wilhelm J, Harms-Ringdahl M. Interaction of lipid peroxidation products with DNA. A review. Mutat Res 1988; 195:137-49.

14. Ashokkumar T. Antioxidants: new-generation therapeutic base for treatment of polygenic disorders. Current Science 2004; 86.

15. Drabkin DL, Austin JH. Spectrophotometric studies I. Spectrophotometric constants for common hemoglobin derivatives in human, dog, and rabbit blood. J Biol Chem 1932; 98:719-33.

16. Yagi K. Lipid peroxides and human diseases. Chem Phy Lipids 1987; 45:337-51.

17. Kakkar P, Das B, Viswanathan P. A modified spectrophotometric assay of superoxide dismutase. Indian J Biochem Biophys. 1984; 21:130-2.
18. Sinha AK. Colorimetric assay of catalase. Anal Biochem 1972; 47:389-94.

19. Sullivan MX CH. Estimation of ascorbic acid. J Assoc of Agric Chem 1955; 38:514.

20. Bieri JG, Teets I, Belavady B, Andrews EL. Serum vitamin $\mathrm{E}$ levels in a normal adult population in Washington, DC, area. Exp Biol Med 1964; 117 : 131-3.

21. Smith JC, Butrimovitz GP, Purdy WC. Direct measurement of zinc in plasma by atomic absorption spectroscopy. Clin Chem 1979; 25 : 1487-91.

22. Pisani P, Parkin D, Ferlay J. Estimates of the worldwide mortality from eighteen major cancers in 1985. Implications for prevention and projections of future burden. Int J Of Cancer 1993; 55:891-903.

23. Messina MJ. Oxidative stress status and cancer: Methodology applicable for human studies. Free Rad Biol Med 1991; 10:175-6.

24. Halliwell B, Gutteridge JM. Free radicals in biology and medicine. Oxford University Press 1999.

25. Huang Y-L, Sheu J-Y, Lin T-H. Association between oxidative stress and changes of trace elements in patients with breast cancer. Clin Biochem 1999; 32:131-6.

26. Khanzode SS, Muddeshwar M, Khanzode SD, Dakhale GN. Antioxidant enzymes and lipid peroxidation in different stages of breast cancer. Free Radic Res 2004; 38:81-5.

27. Boyd NF, McGuire V. The possible role of lipid peroxidation in breast cancer risk. Free Rad Biol Med 1991; 10:185-90.

28. Ray G, Batra S, Shukla NK, et al. Lipid peroxidation, free radical production and antioxidant status in breast cancer. Breast Cancer Res Treat 2000; 59:163-70.

29. Erten Sener D, Gonenc A, Akinci M, Torun M. Lipid peroxidation and total antioxidant status in patients with breast cancer. Cell Biochem Funct 2007; 25:377-82.

30. Polat MF, Taysi S, Gul M, et al. Oxidant/ antioxidant status in blood of patients with malignant breast tumour and benign breast disease. Cell Biochem Funct 2002; 20:327-31.

31. Kasapović J, Pejić S, Todorović A, Stojiljković V, Pajović SB. Antioxidant status and lipid peroxidation in the blood of breast cancer patients of different ages. Cell Biochem Funct 2008; 26:723-30.

32. Suzana S, Normah H, Fatimah A, et al. Antioxidant intake and status, and oxidative stress in relation to breast cancer risk: a case-control study. Asian Pacific J Cancer Prev 2008; 9:343-50.

33. Fathima KP, Deka NJ, Kumar R, Prabasheela B, Anuj Kumar Singh A. Association between Antioxidant Enzymes and Breast Cancer. Rec Res Sci Tech 2011; 3:93-5.

34. Yuvaraj S, Premkumar VG, Vijayasarathy K, Gangadaran SGD, Sachdanandam P. Augmented antioxidant status in Tamoxifen treated postmenopausal women with breast cancer on 